\title{
Investor Protection Laws, Accounting and Auditing Around the World*
}

by

\author{
Jere R. Francis \\ College of Business \\ University of Missouri-Columbia \\ Columbia, MO 65211 \\ Tel.: (573)-882-5156 \\ e-mail: francis@missouri.edu \\ Inder K. Khurana \\ College of Business \\ University of Missouri-Columbia \\ Columbia, MO 65211 \\ Tel.: (573)-882-3474 \\ e-mail:khuranai@missouri.edu \\ Raynolde Pereira \\ College of Business \\ University of Missouri-Columbia \\ Columbia, MO 65211-2437 \\ Tel.: (573)-882-6253 \\ e-mail: pereirar@missouri.edu
}

First draft: March 2001

Current draft: October 2001

Comments Welcome

Please Do Not Quote Without Permission

\footnotetext{
*We appreciate comments of workshop participants at University of Missouri, University of Oklahoma, and the "Workshop on the Future of Audit, Assurance and the Profession" sponsored by the Copenhagen Business School and European Institute for Advanced Studies in Management.
} 


\title{
Investor Protection Laws, Accounting and Auditing Around the World
}

\begin{abstract}
JEL classification: G28; G34; K22; M41; O10

Key Words: Auditing; Accounting standards; Corporate governance; Financial markets;
\end{abstract}

Recent research documents that common law countries have stronger investor protection laws and more developed financial markets than civil law countries (La Porta et al., 1997, 1998). This line of inquiry is extended in our study to examine if variations in legal systems also affect accounting and auditing. For a sample of 31 countries, we document that national accounting standards are more timely (accrual-based) and transparent in common law countries, which is consistent with a greater role played by the public disclosure of accrual-based accounting information in corporate governance in these countries. There is also greater demand for auditing as an enforcement mechanism when accounting is more timely and transparent. We also examine if causality could run from high-quality accounting and auditing to the development of financial markets. La Porta et al. (1998) conjecture that high-quality accounting could mitigate the negative effect of weak investor protection on the development of financial markets. Specifically, we examine if those civil law countries that have more timely and transparent accounting, and more auditing, also have more developed financial markets relative to other civil law countries. We find little support that this is the case, which raises questions about the rationale for the international harmonization of accounting and the work of the International Accounting Standards Committee, absent fundamental changes in investor protection laws of civil law countries. 


\section{Investor Protection Laws, Accounting and Auditing Around the World}

\section{Introduction}

This study uses the investor protection framework of La Porta et al. $(1997,1998)$ to better understand the roles of accounting and auditing in country-specific corporate governance. A series of recent papers document that country-level differences in legal systems with respect to investor protection laws (and the enforcement of such laws) are associated with systematic variations in financial markets. The broadest distinction is between countries based on English common law and which generally have stronger laws and enforcement, versus those based on Roman civil law and which generally have weaker laws and enforcement (La Porta et al., 1998).

The examination of legal systems is motivated by an attempt to explain variations in the development of financial markets across countries. Because managers of firms may not necessarily act in the best interest of all investors, the protection of investor rights, particularly outside (minority) investors, is important in creating economic incentives for the development of financial markets (Hart, 1995). Strong investor protection laws create positive incentives for investments, and La Porta et al. (1997) document that common law countries have more developed financial markets as evidenced by the number of publicly-listed firms and the number of initial public offerings. More developed financial markets create greater external financing opportunities for firms, and La Porta et al. (1997) document that ownership is less concentrated among the largest stockholders in common law countries, leading to more diversified and widespread ownership structures.

Ironically, a consequence of strong investor protection is that agency problems are more likely to exist in common law countries (La Porta et al., 2000b). American style firms with separation of ownership and management are more likely to be found in common law countries, and 
to pose the kinds of classic agency problems described by Berle and Means (1932) and Jensen and Meckling (1976). By contrast, companies in civil law countries are more likely to be owned and controlled by families (or the State) due to weak protection afforded to outside investors, and are therefore less likely to have agency problems (Ball, Kothari and Robin, 2000; La Porta et al., 1999 and 2000a).

Our study extends the seminal work of La Porta et al. $(1997,1998)$ by documenting that national accounting standards are more timely (accrual-based) and transparent in common law countries having stronger investor protection laws and more developed financial markets. Agency problems are greater in common law countries as a consequence of greater external financing, separation of management and ownership, and more diverse ownership structures. In this setting, there is a demand for corporate governance that includes transparent public disclosure of accrualbased accounting. Accrual accounting reflects more timely incorporation of real economic events and therefore better resolves information asymmetries between managers and outside investors than cash-based or tax-oriented accounting systems (Ball, Kothari and Robin, 2000, p. 14). ${ }^{1}$ As timely and transparent accounting becomes important in corporate governance, there is a also a more important role for auditing as an enforcement mechanism in the verification of accounting data (Watts and Zimmerman, 1986, p. 196; Hung, 2000).

The contribution of our study is to carefully document how a country's national accounting standards and enforcement of these standards through auditing are the direct consequence of the country's investor protection laws. By documenting country-specific linkages between investor protection laws, financial markets, and the nature of accounting and auditing in corporate

\footnotetext{
${ }^{1}$ The argument is not pejorative with respect accounting systems in civil law countries. Ball, Kothari and Robin (2000, p. 15) point out that institutional features in civil law countries such as family or state ownership and control, and employee representation on boards, create less distance between the firm and various
} 
governance, we show that investor protection laws have first-order effects on financial markets, the nature of accounting standards, and the demand for auditing as an enforcement mechanism. Our study contributes to the growing body of cross-country research on the value-relevance of accounting numbers, and suggests the results in these studies are really the consequence of underlying investor protection laws. Thus the investor protection framework should be useful in designing future cross-country studies and interpreting the findings of such studies.

The remainder of the paper is divided as follows. The next section elaborates on investor protection in the common law and civil law traditions. Section 3 applies the investor protection framework to develop the hypothesis that accounting is more timely and transparent in common law countries. Auditing plays a critical role as an enforcement mechanism in common law countries in the verification of timely and transparent accounting, and we hypothesize there is both more auditing and more high-quality auditing in these countries relative to civil law countries. The sample, variables and data sources are discussed in section 4. The study's primary results are reported in section 5, and support the country-level linkages between investor protection laws, and the roles of accounting and auditing in corporate governance. In section 6 we also document that the demand for auditing increases in civil law countries that have relatively more timely and transparent accounting. This finding begs the question of whether financial markets are more developed in civil law countries that have relatively more accrual-based accounting and auditing. However, section 7 reports that more accounting/auditing in civil law countries does not result in more developed financial markets. The implication of this finding with respect to the global movement to develop and implement international accounting standards is discussed in the concluding section. 


\section{Common law and civil law traditions}

La Porta et al. $(1997,1998)$ argue that a country’s legal system, in particular commercial law, is not built from scratch but rather relies on borrowed ideas from the available set of legal traditions. Legal traditions have been broadly categorized as either common law or civil law, with civil law countries further divided into three families of legal systems, German, French and Scandinavian (David and Brierly, 1985; Reynolds and Flores, 1989).

In a series of studies La Porta et al. examine whether there are underlying differences across these legal traditions in laws and enforcement of laws that protect investors, and whether these differences can explain the development and structure of financial markets across countries. La Porta et al. (1998) document that legal tradition is an important factor in determining the nature and enforcement of investor protection laws across countries, and that the civil/common law dichotomy is highly correlated with these laws. La Porta et al. (1998) find that common law countries have the strongest investor protection and French civil law countries the weakest protection, with German and Scandinavian civil law countries located in the middle. ${ }^{2}$ Some of the documented features of stronger investor protection include the one-share one-vote rule, the solicitation of proxies by mail (making it easier to mount challenges to directors), cumulative voting or proportional representation

\footnotetext{
${ }^{2}$ Common law originated in Great Britain and is widely adopted in former English colonies that include the United States and Canada. It is derived from decisions made by judges to resolve specific disputes. These rulings are often incorporated into written law by legislatures. In contrast, civil or code law, a derivative of the Roman law tradition, relies on statutes and comprehensive legal codes. Unlike common law, these rules are developed by legal scholars and enacted into commercial code law. The objective is to conceive normative rules of conduct intimately linked to ideas of justice and morality. An additional difference between common and civil law systems is the role played by the judge in the adjudication process (Coffee, 1999a). Under civil law, the judge's role is limited to applying existing codes to cases. If a new issue comes before a court not specifically covered in an existing code, the judge has little discretionary power to deal with it. In contrast, common law courts provide judges much greater discretion in resolving issues. Existing evidence indicates that common law judges apply discretion in favor of outside (minority) shareholders. Protection of outside investor rights is especially important in creating incentives for external investments and the development of financial markets. While the civil/common law dichotomy is a useful categorization, Coffee (1999b) also notes that there are important differences in laws between countries within the same legal tradition.
} 
of minorities on boards of directors, mechanisms to legally safeguard minority investors, preemptive rights to new share issues (to maintain proportional holdings), and the ability to call an extraordinary shareholders' meeting. Stronger enforcement is evaluated by examining factors including the overall efficiency of the legal system, adherence to the rule of law, risk of asset expropriation, repudiation of contracts by governments, and the corruption of government.

The investor protection framework can be summarized as follows. La Porta et al. (1998) demonstrate that investor protection laws are generally stronger in common law countries. La Porta et al. (1997, 1999, 2000a, 2000b) also document that legal tradition affects financial markets, with stronger investor protection laws resulting in more developed financial markets. More developed financial markets lead to greater external financing opportunities, and to more widespread (less concentrated) ownership structures which create potential agency problems. Timely and transparent accounting information can resolve agency problems based on information asymmetry between the firm and outside investors (Ball, Kothari and Robin, 2000). Therefore, greater public disclosure of accrual-based accounting is part of the corporate governance system in countries with strong investor protection laws to meet the need for timely and transparent accounting information. Finally, when accounting is more timely and transparent, auditing is more critical as an enforcement mechanism because accounting itself is more important to outsiders, and also because accrual-based accounting introduces the possibility of managerial opportunism. Luez et al. (2001) do not directly study the effectiveness of auditing, but they do report less earnings management in countries with stronger investor protection, which is consistent with the effectiveness of auditing as an enforcement mechanism in limiting managerial opportunism.

In sum, causality thus runs from investor protection laws, to the development of financial markets, to the roles of timely/transparent accounting and auditing in corporate governance to reduce 
information asymmetry between insiders and outsiders. Figure 1 illustrates the investor protection framework and also clarifies the contribution of our study to the investor protection literature. We extend the framework by incorporating the implications of investor protection for corporate governance and the roles of accounting and auditing. Importantly, the unit of analysis in our study is a country. For a sample of 31 countries we demonstrate the linkage between investor protection laws, the development of financial markets, and the nature of accounting and auditing and their role in corporate governance.

\section{[Insert Figure 1 Here]}

Our study focuses on the left-hand side of Figure 1 and documents country-specific linkages between investor protection and the roles of accounting and auditing in corporate governance. The right-hand side of Figure 1 indicates that the outcome of a country's investor protection laws is manifested in the observed properties of corporate financial statements of the country. Recent studies have begun to examine corporate-level financial statements across countries and to test for differences in the usefulness of accounting numbers for security valuation. The investor protection framework in Figure 1 is helpful in contextualizing and interpreting these studies. Ali and Hwang (2000) find that accounting numbers are more value-relevant in pricing securities in (1) countries that are market-oriented rather than bank-oriented, (2) countries using what is termed a BritishAmerican model of accounting rather than a Continental European model (Nobes, 1998), and (3) countries in which tax rules have less influence on accounting standards. These empirical results can be explained by investor protection laws. Countries with weak investor protection laws are more likely to be bank-oriented than market-oriented because financial markets will not be as developed due to weak investor protection (La Porta et al. 2000b). Similarly, accounting in Continental countries is less likely to be timely (accrual-based) because financial markets are less developed in 
these countries due to weak investor protection. As a consequence there is less widespread ownership and less distance between the firm and stakeholders, which results in less need for timely and transparent accounting in corporate governance. It also follows that accounting which is taxoriented rather than accrual-based is more likely to exist in civil law countries with less developed financial markets where corporate governance does not require timely and transparent accounting.

Studies by Ball, Kothari and Robin (2000) and Guenther and Young (2000) use the civil/common law dichotomy as a framework to explain differences across countries in the properties of accounting numbers and approaches to standard setting. While these studies do not explicitly use La Porta et al.'s investor protection framework, Figure 1 is helpful in understanding the legal foundation underlying the civil/common law categorizations. Ball, Kothari and Robin (2000) and Guenther and Young (2000) make conjectures about the nature of financial markets, the ownership structure of firms, and corporate governance in civil law vs. common law countries that are broadly consistent with La Porta et al. (1997, 1998, 2000a, 2000b) who document these effects as the consequences of underlying differences in investor protection laws between civil law and common law legal traditions.

Hung (2000) explicitly uses the investor protection framework of La Porta et al. to motivate her study. She argues that accrual-based accounting is, in principle, more value-relevant in pricing securities (Dechow, 1994). However, accrual accounting also introduces the possibility of managerial opportunism, which could negate the informational value of accruals. She argues that opportunism is less likely to occur in countries with strong investor protection laws (and enforcement) and therefore accounting will be more value-relevant in these countries. While Hung (2000) invokes the investor protection framework, her study does not clearly articulate the origin of accrual accounting. Accrual accounting is not more value-relevant in common law countries because 
they have better enforcement, as Hung (2000) suggests. Rather, it is because "better" accrual accounting is more likely to exist in common law countries in the first place. That is, strong investor protection in common law countries creates the demand for more timely (accrual-based) and transparent accounting information in corporate governance. Causality runs from investor protection to the demand for timely and transparent accounting (and auditing) in corporate governance.

\section{Investor protection laws and accounting and auditing}

An important distinction between our study and prior cross-country accounting research is that our explicit unit of analysis is a country rather than corporate-level financial statements. This allows us to directly test country-specific linkages between investor protection laws, the development of financial markets, and the nature of accounting and auditing in country-level corporate governance. The three primary hypotheses to be tested draw on Figure 1 and are stated (in alternative form) as follows:

H1: Civil law countries have weak investor protection laws and therefore have less developed financial markets than common law countries (which have stronger investor protection).

H2: $\quad$ Civil law countries have weak investor protection laws and therefore have less timely (accrual-based) and transparent accounting than common law countries (which have stronger investor protection).

H3: Civil law countries have weak investor protection laws and therefore have less demand for auditing as an enforcement mechanism than common law countries (which have stronger investor protection).

We begin our analysis by extending the results of La Porta $(1997,1998)$. Hypothesis H1 tests the effect of investor protection on the development of financial markets. Markets are expected to be less developed in civil law countries due to weaker investor protection. We evaluate the development of financial markets using a measure of liquidity and a measure of overall market capitalization. These two measures have not been examined in prior studies by La Porta et al., but 
they are standard indicators of economic development (Levine, 1997; Levine and Demirguc-Kunt, 1996).

Hypothesis $\mathrm{H} 2$ tests the effect of investor protection on the timeliness and transparency of accounting. Accounting timeliness represents the degree to which a country's national accounting standards are accrual-based. Timeliness is measured using variables that represent the degree to which national standards in a country depart from cash-based or tax-oriented rules, and hence is accrual-based and more likely to measure economic income in a timely manner (Ball, Kothari and Robin, 2000; Guenther and Young, 2000; Hung, 2000). Accounting transparency is the extent to which accounting information is publicly disclosed, and is measured with a disclosure index developed by Center for International Financial Analysis and Research (1993). Hypothesis H2 predicts that accounting is less timely and transparent in civil law countries.

Hypothesis H3 tests the effect of investor protection on the demand for auditing as an enforcement mechanism. The demand for auditing is measured in two ways. First, demand is measured using an estimate of country-level spending on auditing services. A second measure of the demand for auditing is based on the market share in a country held by the elite international Big Five accounting firms. ${ }^{3}$ Numerous studies document that Big Five auditors have brand-name reputations, charge higher audit fees, and behave qualitatively differently from non-Big Five auditors (e.g., Craswell et al., 1995; Becker et al., 1998; Francis et al., 1999; Francis and Krishnan, 1999; Reynolds and Francis, 2000). Hypothesis H3 predicts there is less spending on auditing and less demand for Big Five audits in civil law countries.

\footnotetext{
${ }^{3}$ We use the term "Big Five" even though the main tests in the study are for 1990, which predates the 1998 merger of Coopers \& Lybrand and Price Waterhouse that reduced the then elite Big Six group of accounting firms to the present Big Five.
} 


\section{Sample, variables, and data sources}

The initial time period investigated is 1990 because country-level data on audit spending is presently available only for this year, and because country-level accounting variables also date from the early 1990s. To determine the robustness of our results, some of the models are also estimated using 1998 data. The use of this later year also allows us to extend our empirical analysis to an additional set of explanatory variables and to a time period when many countries began modifying their national accounting standards to incorporate international accounting standards being promulgated by the International Accounting Standards Committee.

The initial sample begins with the 49 countries reported in La Porta et al. (1998). Although our principal focus is on country-level data, we also use company-level data obtained from the Global Vantage database to measure certain country-level variables such as the percentage of companies audited by Big Five accounting firms. However, Global Vantage does not cover companies from 11 of these countries (Pakistan, Sri Lanka, Columbia, Ecuador, Jordan, Nigeria, Egypt, Peru, Philippines, Uruguay, and Venezuela). We also deleted seven countries having fewer than five firms for 1990 in the Global Vantage database. This reduces our sample to 31 countries (see Table 2). For some tests there are fewer countries due to additional data limitations.

Table 1 summarizes the accounting and auditing variables used in the study and the sources of the data for these variables. Additional variables used in the study are also reported in Table 1 and are discussed in the sections where they are used in the analyses.

\section{[Insert Table 1 Here]}

Our hypotheses are that differences in the development of financial markets, and differences in accounting and auditing across countries, are driven by underlying differences in investor protection laws. We test this association using the civil/common law classifications in La Porta et 
al. $(1997,1998)$. The variable CIVIL is a proxy for countries having weak versus strong investor protection laws and is coded one for all countries based on a civil law regime, and zero for all common law countries. There are 11 common countries and 20 civil law countries in the study. As a sensitivity analysis we also test separate indicator variables that correspond to each of the three families of civil law tradition, French, German and Scandinavian. The purpose is to determine if the main results using CIVIL are robust across these subgroups of civil law countries.

Hypothesis H1 predicts that financial markets are more developed in common law countries. The development of financial markets is measured in three ways. The first variable, CAP90, measures a country's total stock market capitalization relative to its 1990 gross domestic product using data from the World Bank (2000). The second variable, LIQ90, represents stock market liquidity. It is defined as the total value of market trading for 1990, as a percentage of a country's gross domestic product and is also obtained from data in the World Bank (2000). Market capitalization (CAP90) and liquidity (LIQ90) are commonly used indicators to measure economic development (Levine, 1997; Levine and Demirguc-Kunt, 1996). The third variable, CAPL, was developed by La Porta et al. (1998) and measures the average percentage of shares not owned by the top three stockholders in a country's 10 largest publicly-traded nonfinancial companies. CAPL is a proxy for stock market capitalization of minority (non-majority) stockholders in countries. La Porta et al. (1998) argue that the percentage of minority stockholdings will be larger in countries having stronger investor protection laws.

Hypothesis $\mathrm{H} 2$ predicts that accounting is more timely and transparent in common law countries. The extent to which a country's national accounting standards are timely or accrual-based is measured in two ways. Following Hung (2000), an accrual index called ACCR is constructed by equally weighting 11 accrual-related national accounting standards as of January 1, 1993 based on 
country-level data in Coopers \& Lybrand (1993). ${ }^{4}$ The eleven accounting standards pertain to the capitalization of goodwill, capitalization of purchased intangibles, capitalization of internally developed intangibles, $R \& D$ expenditures, interest capitalization, lease capitalization, use of equity method for investments, use of the percentage of completion method, use of accelerated depreciation methods, and the accrual of pension benefits and other post-retirement benefits. ACCR has a theoretical range of zero to one, with a larger value indicating accounting standards in a country are more accrual-based.

The second accrual accounting variable is TAXBK, which represents the extent to which a country's financial accounting standards depart from tax rules. Prior studies have shown that accounting earnings are less timely when there is a strong link between tax and financial accounting rules (Ali and Hwang 2000; Guenther and Young, 2000). Again following Hung (2000), the variable TAXBK is constructed from data in Coopers and Lybrand (1993), and assigned a value of one if there is substantial divergence between financial reporting and tax rules, and zero otherwise. ${ }^{5}$

The third accounting variable DISCL is a proxy for accounting transparency and is based on the amount of public financial disclosure in a country. DISCL is obtained for the year 1990 from Center for International Financial Analysis and Research (1993). CIFAR creates a country- specific index by rating the annual reports of at least three firms in every country for inclusion or omission of 90 specific items. The 90 items are based on the presence of specific disclosures in the following seven categories: general information ( 8 items), income statement (11 items), balance sheet (14

\footnotetext{
${ }^{4}$ A potential concern is whether the use of the accounting standards as of January 1, 1993 is representative of the sample year 1990. However, Joos and Lang (1994) point out that harmonizing national accounting standards to achieve greater international conformity is a very slow process.

${ }^{5}$ We use the same criteria and weighting as Hung (2000), which are outlined in Table 1 of her paper. The six criteria are: consensus estimate of the relation between tax and financial reporting; are there deferred taxes; does legal form dominate substance; is there accelerated depreciation; do amortization periods depend on tax laws; and does lease capitalization depend on tax laws. Note that we reverse her coding rule and assign a
} 
items), funds flow statement (5 items), accounting policy disclosure (20 items), shareholders' information (20 items), and other supplementary information (12 items). The disclosures are quantitative (presence/absence) in nature rather than qualitative or evaluative. Each country obtains a score out of 90 with a higher number indicating more public disclosure in financial statements.

In sum, there are three accounting variables in the study. ACCR and TAXBK represent the degree to which a country's financial accounting system is accrual-based and departs from cashbased and tax-oriented rules, respectively. DISCL measures the extent of public financial disclosure and is a proxy for accounting transparency. Hypothesis $\mathrm{H} 2$ predicts that more timely and transparent accounting is required for corporate governance in common law countries (with stronger investor protection) as a consequence of the more developed financial markets in those countries.

Hypothesis $\mathrm{H} 3$ predicts that the demand for auditing as an enforcement mechanism is greater in common law countries. The demand for auditing in a country is measured in two ways. The variable SPEND represents aggregate country-level spending on external auditing services and is estimated using total fees of a country's ten largest accounting firms in 1990 as reported in Jaffe (1992), divided by the country's gross domestic product in 1990 to scale for country size. If data for all 10 accounting firms are not available, we use all available firms. To our knowledge, Jaffe (1992) is the only source for audit fee data across a wide range of countries, and 1990 is the only year for which data are available.

A second measure of the demand for auditing is based on the market share in a country held by the elite Big Five accounting firms. The market share variable B590 is based on country-specific data in the Global Vantage database for fiscal 1990. For each country, B590 is calculated as the sum of square root of total assets of each Big Five audit client, divided by the sum of square root of total 
assets of all firms for that country in the database. ${ }^{6}$ A higher Big Five market share indicates greater demand for high-quality auditing within a country.

\section{Primary results}

Table 2 reports descriptive statistics for variables used in the study. Values are reported for each of the countries in the study, and we test if median values of common law countries differ from those of civil law countries. Common law countries are also compared with each of the three civil law groups of countries (French, German, Scandinavian).

[Insert Table 2 Here]

The results in Table 2, Panel E, support the study's primary hypotheses. Financial markets are more developed in common laws countries (H1), as the variables CAP90, CAPL and LIQ90 all have larger values in common law countries. There is also more timely and transparent accounting in common law countries (H2). Common law countries have more accrual-based standards (ACCR), greater divergence between financial reporting and tax rules (TAXBK), and greater public disclosure (DISCL). Finally, there is more Big Five auditing (H3) in common law countries, though no difference in spending on audits (SPEND) is evident in the univariate test in Table 2. ${ }^{7}$

While the univariate tests in Table 2 generally support the study's primary hypotheses, a further analysis of the accounting variables is reported in Table 3. Each accounting measure is

\footnotetext{
${ }^{6}$ We use square root of assets to proxy for the share of industry output (audit fees) held by Big Five firms. The square root of assets is used because audit fees are nonlinear and increase as company size increases, but at a decreasing rate. An alternative country-level variable is based on the ratio of total Big Five clients to the total number of audit clients reported in the Global Vantage database. A higher proportion is again indicative of greater demand for high-quality auditing. Results are comparable using both measures.

${ }^{7}$ Table 2 also reports separate tests for each of the three civil law subgroups. For the variables measuring the development of financial markets, these additional tests show that the French civil law countries drive the statistical differences. For the accounting variables, the differences are robust across all three civil law groups except the variable DISCL for Scandinavian countries. For Big Five auditing, the differences are driven by German and Scandinavian civil law countries.
} 
regressed on civil law indicator variables plus a control variable for country wealth, LGNP90, which is the natural log of a country's gross national product per capita in 1990. Wealthier countries are better able to afford costly accrual-based financial reporting systems and more extensive auditing, irrespective of investor protection laws. ${ }^{8}$

[Insert Table 3 Here]

Two sets of estimations are reported in Table 3. Panel A uses the civil/common law dichotomy, while Panel B uses three separate civil law indicator variables. The regression results in Table 3 corroborate the tests reported in Table 2, and provide even stronger support for all three of the study's primary hypotheses. In Panel A, all variables for financial market development, accounting, and auditing are significant in the predicted direction. Financial markets are less developed in civil law countries (H1); there is less disclosure of timely (accrual-based) accounting in civil law countries (H2); and there is less spending on auditing and less demand for Big Five audits in civil law countries (H3). Panel B shows that these results are robust across all three civil law groups with only one exception, the accounting disclosure variable (DISCL) for Scandinavian countries. On the basis of these results, all of the remaining tests in the paper are reported using the simpler civil/common law dichotomy. ${ }^{9}$

\section{[Insert Table 3 Here]}

Additional models are reported in Table 4 to test a direct association between the accounting variables and the demand for auditing as an enforcement mechanism. The models in Table 4 regress

\footnotetext{
${ }^{8}$ La Porta et al. (1998) use log of GNP per capita, as well as the log of GNP, as control variables for country wealth. Our results are comparable when log of GNP is used in lieu of log of GNP per capita.

${ }^{9}$ As a sensitivity analysis, we use a composite index of investor protection developed in La Porta et al. (1997) in lieu of the civil law indicator variables. This index is based on six specific elements of investor protection and country-level scores can range from zero to six. This index, termed anti-director rights, is substituted for CIVIL, and the results are consistent with those reported in Table 3. That is, countries with stronger investor
} 
the auditing variables (SPEND and B590) on each of the accounting variables, plus a control variable for country wealth (LGNP90). In columns (1), (2), and (3), each accounting variable is positively related to the amount of audit spending (SPEND) and is significant at $\mathrm{p}<.05$. In columns (7) and (8), the accrual variables ACCR and TAXBK are positively related to Big Five market share at $p<.01$. The only insignificant result is the model in column (9) in which there is no association between DISCL and the demand for a Big Five audit. Overall, these six regressions supplement the primary findings in Table 3 by showing a direct association between timely and transparent accounting, and the demand for auditing as an enforcement mechanism in corporate governance.

[Insert Table 4 Here]

Up to this point we have tested the link between investor protection laws and the development of financial markets, and the related effect on the roles of accounting and auditing in corporate governance. Our findings indicate that civil law countries have less developed financial markets, less timely and less transparent accounting, and less demand for auditing, relative to common law countries.

Our next analysis determines if more timely/transparent accounting within civil law countries affects the demand for auditing in these countries. The purpose is to assess if there is greater demand for auditing (enforcement) in civil countries that have relatively more timely and transparent accounting than other civil law countries. It is intuitive that there should be more auditing in those civil law countries that have relatively more public disclosure of accrual-based accounting in their national accounting standards. Hypothesis $\mathrm{H} 4$ is stated (in alternative form) as follows:

H4: $\quad$ Civil law countries with relatively more transparent/timely accounting will have a greater demand for auditing than other civil law countries.

protection have more developed financial markets, more transparent and timely accounting, and more auditing. 
To test H4, the auditing variables SPEND and B590 are regressed on CIVIL, interaction terms in which CIVIL is interacted with each of the accounting variables, and a control variable for country wealth (LGNP90). If the interaction terms are positive, then there is evidence that more auditing is demanded in civil law countries that have more timely and transparent accounting. The six models reported in columns (4), (5), (6), (10), (11) and (12) in Table 4 test these interaction effects. There is some support for hypothesis $\mathrm{H} 4$ as three of the six models indicate that the demand for auditing is greater in civil law countries that have relative more accrual-based accounting. In column (5), the interaction of the accounting variable TAXBK with the civil law indicator variable CIVIL is positively related to audit spending, and in columns (10) and (11) the interactions of the accrual accounting variables ACCR and TAXBK with the civil law indicator variable CIVIL are positively related to Big Five market share. These results provide evidence that there is some degree of variation in accrual-based accounting within the civil law group of countries, and this variation affects the demand for auditing in these countries - even though civil law countries as a group have less accrual-based accounting than common law countries.

\section{Demand for big five audits in $\mathbf{1 9 9 8}$}

The analyses reported in Tables 2 through 4 are based on data from the early 1990s. Legal systems change slowly and are unlikely to be substantially different today than they were in the early 1990s, although there is an emerging movement for stronger investor protection in civil law countries (see Tagliabue, 2001). However, there have been other important developments since the early 1990s with respect to international growth of the Big Five accounting firms, global harmonization of accounting standards through the work of the International Accounting Standards Committee, and cross-border listing of securities in the United States. In this section we examine 
how these developments have affected the demand for Big Five audits. For this analysis we use 1998 data from the Global Vantage database to measure Big Five market shares in countries.

In Table 5, Panel A, the model in column (1) regresses 1998 Big Five market share on a civil law indicator variable plus a control variable for country wealth as in other regressions. The result is comparable to that reported in Table 3 using 1990 data. Big Five market share is significantly greater in common law countries $(\mathrm{p}<.05)$, in both 1990 and 1998.

[Insert Table 5 Here]

The next analysis in Table 5, Panel A, examines the effects of international accounting standards and the cross-listing of securities in the United States on the demand for Big Five audits in civil law countries. The purpose is to determine if a higher frequency of international accounting standards or U.S. cross-listings increase the demand for an international Big Five auditor within civil law countries. This constitutes a further test of $\mathrm{H} 4$ and the expectation is that civil law countries with more accrual-based accounting, as evidence by the use of either international accounting standards or cross-listing of securities in the U.S., will have a demand for more Big Five audits.

Using data from the International Accounting Standards Committee (2001), the variable IAS is coded one for countries that permit companies to use international accounting standards or if international accounting standards are used as a basis for developing national standards. The IASC standards are widely viewed as accrual-based and derived mainly from British-American standards (Ball, Kothari and Robin, 2000, p. 47). A second variable, IASPRO, is created using firm-level data in Global Vantage to measure the proportion of companies within a country coded by Global Vantage as using either international standards or U.S. accounting standards. Thus IAS is an indicator variable simply denoting if international standards are possible for companies within a 
country, while IASPRO measures the proportion of companies actually using either IASC or U.S. accounting standards. ${ }^{10}$

The models in columns (2) and (3) of Table 5, Panel A, indicate that neither the introduction of optional reporting based on international accounting standards (IAS) nor the proportion of companies using international or U.S. standards (IASPRO) affects the demand for Big Five audits. However, the model in column (4) indicates greater demand for Big Five audits in countries with higher proportions of companies that cross-list in the United States, using the variable CLS which is from a study by Reese and Weisbach (2000). This is intuitive since cross-listing requires reconciliation of foreign-based financial statements to U.S. accounting standards. In addition, the primary reason for cross-listing in the U.S. is to access a larger financial market, and this incentive will be greater in civil law countries with weaker investor protection laws and less developed domestic financial markets.

A sensitivity analysis is reported in Table 5, Panel B, using just the civil law countries. For the group of civil law countries, Big Five market share is regressed on each of the three accounting variables evaluated in Panel A. Panel B reports evidence that Big Five market share in civil law countries is greater for countries that make international accounting standards optional (IAS), for countries that have a greater proportion of companies actually using international accounting standards (IASPRO), and for countries having a greater proportion of companies cross-listing in the U.S. (CLS).

The results in Panel B of Table 5 corroborate and extend the results in Table 4, demonstrating that the demand for Big Five audits increases as accounting becomes more accrualbased in civil law countries. Table 4 shows an increase in both audit spending and Big Five audits

\footnotetext{
${ }^{10}$ An alternative coding of the variable IAS is also tested based on a 1996 country-level survey conducted by
} 
related to the accrual accounting variables ACCR and TAXBK, and Table 5 shows an increase in Big Five audits associated with the use of accrual-based international accounting standards and cross-listing of securities in the United States (which requires a reconciliation to accrual-based U.S. accounting standards). Together these two tables provide strong support for hypothesis $\mathrm{H} 4$ that there is a greater demand for auditing (enforcement) as accounting within civil law countries becomes more accrual-based.

\section{Does accounting and auditing really matter in civil law countries?}

Thus far our tests indicate that more timely and transparent accounting exists in common law countries having stronger investor protection (and more developed financial markets), and that more auditing is demanded as a function of the more transparent and accrual-based accounting in these countries. In terms of Figure 1, causality flows from left to right: from investor protection laws, to the development of financial markets, to the role of accounting and auditing in corporate governance. However, is it possible that causality runs in the opposite direction in Figure 1? Is it possible that accounting and auditing affect the development of financial markets, independent of investor protection laws? La Porta et al (1998, p. 1140) conjecture that high-quality accounting could substitute for weak investor protection laws and lead to more developed financial markets.

Despite their conjecture, La Porta et al. (1998) do not directly test if accounting has a positive effect on financial markets in civil law countries with weak investor protection. We test their conjecture and examine if more timely and transparent accounting, and more auditing, in civil law countries is positively associated with the development of financial markets. This conjecture is clearly a reasonable possibility because models we report in Tables 4 and 5 document that some civil

the International Accounting Standards Board (1997). 
laws countries do have relatively more timely/transparent accounting and more auditing than other civil law countries. The following hypothesis (stated in alternative form) is tested:

H5: Civil law countries with relatively more transparent/timely accounting, and relatively more auditing, will have more developed financial markets than other civil law countries.

The test of H5 is reported in Table 6. The three measures of financial market development are regressed on CIVIL, interaction terms in which CIVIL is interacted with each of the accounting and auditing variables, and a control variable for country wealth. Most the 15 models reported in Table 6 indicate that civil law countries have less developed financial markets as measured by CAP90, CAPL and LIQ90. The variable CIVIL is significant and negatively associated with financial market development in 12 of the 15 models. This finding is consistent with and extends the results in La Porta et al. (1997). More importantly, there is no evidence from any of the 15 models that more timely/transparent accounting in civil law countries, or more auditing, has an impact on the development of financial markets. None of the interaction terms in Table 6 is significant. A further regression analysis (not reported) uses only civil law countries and also finds that none of the accounting/auditing variables is significantly associated with the development of financial markets as measured by CAP90, CAPL or LIQ90. These findings reject the conjecture that high-quality accounting (and enforcement through auditing) might substitute for weak investor protection in civil law countries.

\section{[Insert Table 6 Here]}

The accounting variables used in the analysis in Table 6 date from the early 1990s. Since then, there has been considerable push for global harmonization of accounting standards and development of standards by the International Accounting Standards Committee (2001). The argument for international accounting standards (in lieu of national accounting standards) is premised on the belief that the adoption of accrual-based international standards will improve 
national capital markets by improving the quality of accounting information reported by companies in these countries (Barth et al., 1999, p. 202). The international accounting movement therefore presumes the adoption of uniform accrual-based accounting standards will have a positive impact on financial markets. For example, Levitt (1998, p. 81) asserts, "high quality accounting standards result in greater investor confidence, which improves liquidity, reduces capital costs, and makes fair market prices possible." However, more accrual accounting (alone) may not necessarily affect financial markets in countries if underlying investor protection laws remain weak and create disincentives for investors. Thus it is an empirical question whether more transparent accrual-based accounting (alone) can positively affect the development of financial markets in countries with weak investor protection laws.

We use data from 1998 to test if the adoption of accrual-based IASC standards or the greater use of Big Five auditors within civil law countries affects the development of financial markets relative to other civil law countries. The variables IAS and IASPRO (see Table 5) represent the degree to which international (accrual-based) standards are being used, and B598 represent countrylevel Big Five market shares (see Table 5). CAP98 and LIQ98 are used to measure the development of financial markets in 1998 and are defined analogously to CAP90 and LIQ90 (see Table 1). Table 7 reports the regressions of CAP98 and LIQ98 on the variable CIVIL, plus interaction terms in which CIVIL is interacted with IAS, IASPRO, and B598, plus a control variable for country wealth (LGNP98). As was the case in Table 6 for 1990, civil law countries have less developed financial markets as evidenced by the negative and significant coefficient on the variable CIVIL for all six models in Table 7. Of the six models, only the model in column (3) provides any evidence $(\mathrm{p}<.05)$ that civil law countries have relatively more developed financial markets as the proportion of companies using accrual-based international or U.S. accounting standards increases (IASPRO). 
This is a potentially important finding, and suggests there could be an economic rationale for the global movement to harmonize accounting standards by the International Accounting Standards Committee. $^{11}$

\section{[Insert Table 7 Here]}

Unfortunately, further analysis reveals that two countries, Switzerland and Italy, are extreme outliers that drive the statistical association between IASPRO and CAP98. The variable IASPRO has a value of $42 \%$ for Switzerland and $33 \%$ for Italy. ${ }^{12}$ The next largest value of IASPRO is $13 \%$ for Germany. All remaining civil law countries have values of less than 10\%, including seven countries with values of zero. When the model in column (3) of Table 7 is re-estimated dropping Switzerland and Italy, the t-statistic on the interaction of CIVIL and IASPRO is -0.22 and insignificant. Thus for 17 of the 19 civil law countries in the study, there is no evidence that either IAS or IASPRO has any impact on the development of financial markets.

The evidence reported in this section does not support that changes in accounting and auditing, alone, independent of changes in underlying investor protection laws, can bring about the development of financial markets. The analyses in Table 6 and Table 7 reject hypothesis $\mathrm{H} 5$ and instead support the argument that causality in Figure 1 goes from left to right, from investor protection laws, to the development of financial markets, to the roles of timely/transparent accounting and auditing as an enforcement mechanism in corporate governance.

\footnotetext{
${ }^{11}$ The possibility that accrual-based accounting leads to more developed financial markets is consistent with arguments made in the early 1900s by the German economist, Werner Sombart, who argued that advances in double-entry accounting were instrumental in the development of market-based capitalism and the emergence of modern corporations (Yamey, 1964; Most, 1972). Watts and Zimmerman (1983) develop similar arguments concerning the historical role of auditing in economic development.

${ }^{12}$ We have no explanation for why Italy and Switzerland have such a larger proportion of companies on the Global Vantage database that use international or U.S. standards. There may be institutional factors unique to these countries that results in greater use of accrual accounting and more developed financial markets than in other civil law countries in the study.
} 


\section{Conclusions}

This study uses an investor protection legal framework to explain country-level differences in the role of accounting and auditing in corporate governance. La Porta et al. $(1997,1998)$ demonstrate that civil law countries have weaker investor protection laws and, as a consequence, less developed financial markets. We hypothesize there is also more demand for timely and transparent accounting in corporate governance of common law countries because financial markets are more developed in these countries, and timely and transparent accounting resolves information asymmetries between the firm (including inside owners) and outside investors. Our analysis supports this prediction. Three measures of accounting are evaluated and indicate that common law countries have more transparent public disclosure and more timely (accrual-based) accounting. In addition, there is more spending on auditing as an enforcement mechanism in common law countries, and larger market shares by the elite Big Five accounting firms. We also document that there is accounting variation within civil law countries, and that more timely and transparent accounting within civil law countries also leads to more spending on auditing and a greater market share by Big Five auditors within these countries.

Finally, we consider whether causality could run from accounting/auditing to the development of financial markets (opposite the direction depicted in Figure 1). La Porta et al. (1998) conjecture that "strong" accounting could compensate for "weak" investor protection laws. Global accounting harmonization is appealing in this context because it is likely to be far easier to make accounting changes in civil law countries through the adoption of international accounting standards, than to undertake more fundamental legal reform of investor protection laws. Thus if the adoption of accrual-based international accounting standards leads to greater development of local financial markets, there would exist a persuasive economic argument in favor of international 
accounting standards - at least for those countries having weak investor protection laws and national accounting standards that are not transparent or timely. However, except for Switzerland and Italy, we find no evidence that civil law countries adopting international accounting standards have more developed financial markets than other civil law countries. Thus accounting per se does not appear to affect the development of financial markets; rather, it seems that both accounting systems and financial markets are the consequences of underlying legal systems that protect investors. Therefore, like Ball (1995) and Ball, Robin and Wu (2000) we are skeptical about the motives for and benefits of global accounting harmonization. Absent changes in investor protection laws, it is unclear what the effect of harmonization is, particularly for civil law countries, other than creating more demand for auditing. At a minimum there is a need for further research investigating the economic benefits of implementing costly accrual-based financial reporting systems in countries that have weak investor protection laws. 


\section{References}

Ali, A. and L. Hwang. 2000. Country-specific factors related to financial reporting and the value relevance of accounting data. Journal of Accounting Research 38 (Spring), 1-21.

Ball, R. 1995. Making accounting more international, how, and how far will it go? Journal of Applied Corporate Finance 8 (Fall), 19-29.

Ball, R., S. Kothari, and A. Robin. 2000. The effect of international institutional factors on properties of accounting earnings. Journal of Accounting and Economics 29 (February), 151.

Ball, R., A. Robin, and J. Wu. 2000. Accounting standards, the institutional environment and issuer incentives: Effect on timely loss recognition in China. Asia-Pacific Journal of Accounting and Economics 7 (December), 71-96.

Barth, M., G. Clinch, and T. Shibano. 1999. International accounting harmonization and global equity markets. Journal of Accounting and Economics 26 (January), 201-235.

Becker, C., M. DeFond, J. Jiambalvo, and K. Subramanyam. 1998. The effect of audit quality on earnings management. Contemporary Accounting Research 15 (Spring), 1-24.

Berle, A. and G. Means. 1932. The modern corporation and private property (Macmillan, New York).

Center for International Financial Analysis and Research. 1993. Global company handbook, $2^{\text {nd }}$ edition, Volume 4 (Center for International Financial Analysis and Research, Princeton).

Coffee, J. 1999a. The future as history: The prospects for global convergence in corporate governance and its implications. Northwestern University Law Review, 641-708.

Coffee, J. 1999b. Privatization and corporate governance: The lessons from securities market failure. Journal of Corporation Law 12, 1-39.

Coopers \& Lybrand. 1993. International accounting summaries: A guide for interpretation and comparison, $2^{\text {nd }}$ ed. (Wiley, New York).

Craswell, A., J. Francis, and S. Taylor. 1995. Auditor brand name reputations and industry specializations. Journal of Accounting and Economics 20 (December), 297-322.

David, R. and J. Brierly. 1985. Major legal systems in the world today (Stevens and Sons, London).

Dechow, P. 1994. Accounting earnings and cash flows as measures of firm performance: The role of accounting accruals. Journal of Accounting and Economics 18 (July), 3-42. 
Francis, J. and J. Krishnan. 1999. Accounting accruals and auditor reporting conservatism. Contemporary Accounting Research 16 (Spring), 135-165.

Francis, J., E. Maydew, and H.C. Sparks. 1999. The role of big 6 auditors in the credible reporting of accruals. Auditing: A Journal of Practice and Theory 18 (Fall), 17-34.

Guenther, D. and D. Young. 2000. The association between financial accounting measures and real economic activity: A multinational study. Journal of Accounting and Economics 28 (February), 53-72.

Hart, O. 1995. Firms, contracts, and financial structure (Oxford University Press, London).

Hung, M. 2000 Accounting standards and value relevance of financial statements: An international analysis. Journal of Accounting and Economics 30 (December), 401-420.

International Accounting Standards Board. 1997. Insight (October 1997).

International Accounting Standards Board. 2001. Use of IAS in countries around the world. http://www.iasc.org.uk/frame/cen1_12a.htm.

Jaffe, L. 1992. The 1992 international accounting databook (Lafferty Publications Ltd, Dublin).

Jensen, M.C. and W.H. Meckling. 1976. Theory of the Firm: Managerial Behavior, Agency Costs and Ownership Structure. Journal of Financial Economics 3 (October), 305-360.

Joos, P. and M. Lang. 1994. The effects of accounting diversity: Evidence from the European Union. Journal of Accounting Research 32 (Supplement), 141-168.

La Porta, R., F. Lopez-de-Silanes, A. Shleifer, and R. Vishny. 1997. Legal determinants of external finance. Journal of Finance 52 (July), 1131-1150.

La Porta, R., F. Lopez-de-Silanes, A. Shleifer, and R. Vishny. 1998. Law and finance. Journal of Political Economy 106 (December), 1113-1155.

La Porta, R., F. Lopez-de-Silanes, and A. Shleifer. 1999. Corporate ownership around the world. Journal of Finance 54 (April), 471-517.

La Porta, R.. F. Lopez-de-Silanes, A. Shleifer, and R. Vishny. 2000a. Agency problems and dividend policies around the world. Journal of Finance 55 (February), 1-33.

La Porta, R., F. Lopez-de-Silanes, A. Shleifer, and R. Vishny. 2000b, Investor protection and corporate governance. Journal of Financial Economics 58 (January), 3-27.

Levine, R. 1997. Financial development and economic growth: views and agenda. Journal of Economic Literature 35 (June), 688-726. 
Levine, R., and A. Demirguc-Kunt. 1996. Stock market development and financial intermediary growth: stylized facts. World Bank Economic Review (May).

Levitt, A. 1998. The importance of high quality accounting standards. Accounting Horizons 12 (March), 79-82.

Luez, C., D. Nanda, and P. Wysicki. 2001. Investor protection and earnings management: an international comparison. Unpublished Paper (University of Pennsylvania, PA; University of Michigan, MI; Massachusetts Institute of Technology, MA).

Most, K. 1972. Sombart's propositions revisited. The Accounting Review 47 (October), 722-734.

Nobes, C. 1998. Towards a general model of the reasons for international differences in financial reporting. Abacus 34 (September), 162-187.

Reynolds, J.K. and J. Francis. 2000. Does size matter? The influence of large clients on office-level auditor reporting decisions. Journal of Accounting and Economics 30 (December), 375-400.

Reynolds, T. and A. Flores. 1989. Foreign law: Current sources of basic legislation in jurisdictions of the world (Rothman and Co., Littleton, $\mathrm{CO}$ ).

Tagliabue, J. 2001. Europeans' rallying cry: One share, one vote! The New York Times (June 10, Section 3, Money and Business), 1 and 14.

Watts, R., J. Zimmerman. 1983. Agency problems, auditing, and the theory of the firm: Some evidence. Journal of Law and Economics 26 (October), 613-634.

Watts, R. and J. Zimmerman. 1986. Positive accounting theory (Prentice-Hall, Englewood Cliffs, $\mathrm{NJ})$.

Weisbach, M. and W. A. Rees, Jr. 2000. Protection of minority shareholder interests, cross-listings in the United States, and subsequent equity offerings. Unpublished paper (University of Illinois at Urbana-Champaign, IL).

World Bank. 2000. World development indicators (World Bank, Washington, D.C.).

Yamey, B. 1964. Accounting and the rise of capitalism: Further notes on a theme by Sombart. Journal of Accounting Research 2 (Spring), 117-136. 
Table 1

Description of variables

\begin{tabular}{|c|c|c|c|}
\hline Variable & & Description & Source \\
\hline \multirow{4}{*}{$\begin{array}{l}\text { Legal origin of } \\
\text { the Company } \\
\text { Law or } \\
\text { Commercial } \\
\text { Code }\end{array}$} & CIVIL & $\begin{array}{l}\text { Indicator variable equals } 1 \text { if the legal origin is Code Law; } 0 \\
\text { otherwise. }\end{array}$ & $\begin{array}{l}\text { Reynolds and Flores } \\
\text { (1989) and La Porta } \\
\text { et al. (1998). }\end{array}$ \\
\hline & FRENCH & $\begin{array}{l}\text { Indicator variable equals } 1 \text { if the origin is French Law; } 0 \\
\text { otherwise. }\end{array}$ & \\
\hline & GERMAN & $\begin{array}{l}\text { Indicator variable equals } 1 \text { if the origin is German Law; } 0 \\
\text { otherwise. }\end{array}$ & \\
\hline & $\begin{array}{l}\text { SCANDI- } \\
\text { NAVIAN }\end{array}$ & $\begin{array}{l}\text { Indicator variable equals } 1 \text { if the origin is Scandinavian Law; } 0 \\
\text { otherwise. }\end{array}$ & \\
\hline $\begin{array}{l}\text { Stock market } \\
\text { capitalization } \\
\text { to GDP }\end{array}$ & $\begin{array}{l}\text { CAP90, } \\
\text { CAP98 }\end{array}$ & $\begin{array}{l}\text { The ratio of the stock market capitalization to gross domestic } \\
\text { product for } 1990 \text { (1998). }\end{array}$ & World Bank (2000) \\
\hline $\begin{array}{l}\text { External } \\
\text { cap/GNP }\end{array}$ & CAPL & $\begin{array}{l}\text { The ratio of the stock market capitalization held by minorities to } \\
\text { gross GNP national product for } 1994 \text {. The stock market } \\
\text { capitalization held by minorities is computed as the product of the } \\
\text { aggregate stock market capitalization and the average percentage } \\
\text { of common shares not owned by the top three shareholders in the } \\
\text { ten largest non-financial, privately- owned domestic firms in a } \\
\text { given country. A firm is considered privately owned if the State is } \\
\text { not a known shareholder in it. }\end{array}$ & $\begin{array}{l}\text { La Porta et al. } \\
\text { (1998) }\end{array}$ \\
\hline $\begin{array}{l}\text { Market } \\
\text { Liquidity }\end{array}$ & LIQ90, LIQ98 & Total value traded as a percentage of GDP in 1990 (1998). & World Bank (2000) \\
\hline Accrual Index & ACCR & $\begin{array}{l}\text { Index created to measure the degree to which the accounting } \\
\text { system deviates from a cash measure of performance. A higher } \\
\text { index value indicates more accrual-based accounting. }\end{array}$ & $\begin{array}{l}\text { Coopers \& Lybrand } \\
\text { (1993) and Hung } \\
\text { (2000) }\end{array}$ \\
\hline $\begin{array}{l}\text { Tax-book } \\
\text { conformity } \\
\text { index }\end{array}$ & TAXBK & $\begin{array}{l}\text { Indicator variable equals } 1 \text { if tax accounting and financial reporting } \\
\text { diverge; } 0 \text { otherwise. A value of } 1 \text { indicates accounting is more } \\
\text { accrual-based and less tax-based. }\end{array}$ & $\begin{array}{l}\text { Coopers \& Lybrand } \\
\text { (1993) and Hung } \\
\text { (2000) }\end{array}$ \\
\hline $\begin{array}{l}\text { Accounting } \\
\text { Disclosure }\end{array}$ & DISCL & $\begin{array}{l}\text { Index created by examining and rating companies' } 1990 \text { annual } \\
\text { reports on their inclusion or omission of } 90 \text { items. These items fall } \\
\text { into seven categories (general rating information, income } \\
\text { statements, balance sheets, fund flow statements, accounting } \\
\text { standards, stock data, and special items). A minimum of three } \\
\text { companies in each country was studied. A higher value indicates } \\
\text { more public disclosure and therefore more transparent accounting. }\end{array}$ & $\begin{array}{l}\text { Center for } \\
\text { International } \\
\text { Financial Analysis } \\
\text { and Research (1993) }\end{array}$ \\
\hline $\begin{array}{l}\text { Spending on } \\
\text { audit services }\end{array}$ & SPEND & $\begin{array}{l}\text { Total fees of country's ten largest accounting firms (or all } \\
\text { available data where } 10 \text { firms auditing were not available) as a } \\
\text { percentage of the country's gross domestic product for } 1990 \text {. }\end{array}$ & Jaffe (1992) \\
\hline
\end{tabular}


Table 1 (continued) Description of variables

\begin{tabular}{|c|c|c|c|}
\hline Variable & & Description & Source \\
\hline $\begin{array}{l}\text { Big Five market share } \\
\text { based on audited total } \\
\text { assets }\end{array}$ & $\begin{array}{l}\text { B590, } \\
\text { B598 }\end{array}$ & $\begin{array}{l}\text { Ratio of the sum of the square root of the total assets in } 1990 \\
\text { (1998) of all clients of Big Five auditors in a country relative to } \\
\text { the sum of the square root of the total assets in } 1990 \text { (1998) of } \\
\text { all clients of all auditors in that country. }\end{array}$ & $\begin{array}{l}\text { Global Vantage } \\
(2000)\end{array}$ \\
\hline GNP per capita & $\begin{array}{l}\text { GNP90, } \\
\text { GNP98 }\end{array}$ & GNP per capita in US \$ in 1990 (1998). & World Bank (2000) \\
\hline IAS adoption & IAS & $\begin{array}{l}\text { Indicator variable equals } 1 \text { if either domestic firms are allowed } \\
\text { to use international accounting standards for financial reporting } \\
\text { or if international accounting standards are used (in 2001) as a } \\
\text { basis for developing accounting standards; } 0 \text { otherwise. }\end{array}$ & IASC (2001) \\
\hline $\begin{array}{l}\text { Proportion of firms } \\
\text { using international or } \\
\text { US standards }\end{array}$ & IASPRO & $\begin{array}{l}\text { Percentage of the number of all firms using international or US } \\
\text { accounting standards in } 1998 \text { relative to all firms covered by } \\
\text { Global Vantage for that country. }\end{array}$ & $\begin{array}{l}\text { Global Vantage } \\
(2000)\end{array}$ \\
\hline $\begin{array}{l}\text { Cross Listings in the } \\
\text { US per } 100 \text { domestic } \\
\text { listed firms }\end{array}$ & CLS & $\begin{array}{l}\text { Total number of firms cross-listed in the United States (both } \\
\text { depositary receipts and direct cross-listings) from each country } \\
\text { per } 100 \text { domestic listed firms. }\end{array}$ & $\begin{array}{l}\text { Reese and } \\
\text { Weisbach (2000), } \\
\text { Worldscope (1999) }\end{array}$ \\
\hline
\end{tabular}


Table 2

Country-specific characteristics

Panel A: Common law countries

\begin{tabular}{|c|c|c|c|c|c|c|c|c|}
\hline COUNTRY & CAP90 & CAPL & LIQ90 & ACCR & TAXBK & DISCL & SPEND & B590 \\
\hline Australia & 0.36 & 0.49 & 13.5 & 0.82 & 1 & 75 & 0.42 & 0.75 \\
\hline Canada & 0.42 & 0.39 & 12.4 & 0.82 & 1 & 74 & 0.35 & 0.95 \\
\hline Hong Kong & 1.12 & 1.18 & 46.3 & 0.64 & 1 & 69 & 0.004 & 0.76 \\
\hline India & 0.12 & 0.31 & 6.8 & 0.55 & 1 & 57 & 0.001 & 0.06 \\
\hline Ireland & - & 0.27 & 10.63 & 0.82 & 1 & - & 0.63 & 0.96 \\
\hline New Zealand & 0.21 & 0.28 & 4.5 & 0.73 & 1 & 70 & 0.126 & 0.89 \\
\hline Singapore & 0.93 & 1.18 & 55.4 & 0.64 & 1 & 78 & - & 0.92 \\
\hline South Africa & 1.23 & 1.45 & 7.3 & 0.68 & 1 & 70 & 0.36 & 0.8 \\
\hline Thailand & 0.28 & 0.56 & 26.8 & - & - & 64 & 0.017 & 0.32 \\
\hline U K & 0.87 & 1 & 28.6 & 0.82 & 1 & 78 & 0.54 & 0.89 \\
\hline USA & 0.55 & 0.58 & 31.5 & 0.86 & 1 & 71 & 0.24 & 0.98 \\
\hline Median & $\mathbf{0 . 4 2}$ & $\mathbf{0 . 5 3}$ & $\mathbf{1 3 . 5}$ & $\mathbf{0 . 8 2}$ & $\mathbf{1}$ & $\mathbf{7 0}$ & $\mathbf{0 . 2 9 5}$ & $\mathbf{0 . 8 9}$ \\
\hline
\end{tabular}

Panel B: French civil law countries

\begin{tabular}{|c|c|c|c|c|c|c|c|c|}
\hline COUNTRY & CAP90 & CAPL & LIQ90 & ACCR & TAXBK & DISCL & SPEND & B590 \\
\hline Argentina & 0.02 & 0.07 & 0.6 & 0.64 & 1 & - & 0.001 & - \\
\hline Belgium & 0.33 & 0.17 & 3.3 & 0.68 & 0 & 61 & 0.12 & 0.26 \\
\hline Brazil & 0.04 & 0.18 & 1.2 & 0.32 & 1 & - & 0.027 & - \\
\hline France & 0.26 & 0.23 & 9.8 & 0.64 & 0 & 69 & 0.14 & 0.39 \\
\hline Greece & 0.18 & 0.07 & 4.7 & 0.55 & - & 55 & 0.01 & - \\
\hline Italy & 0.14 & 0.08 & 3.9 & 0.45 & 0 & 62 & 0.03 & 0.99 \\
\hline Mexico & 0.12 & 0.22 & 4.6 & 0.55 & - & 60 & 0.007 & - \\
\hline Netherlands & 0.42 & 0.52 & 14.2 & 0.73 & 0 & 64 & 0.6 & 0.92 \\
\hline Portugal & 0.13 & 0.08 & 2.4 & 0.55 & - & - & 0.12 & - \\
\hline Spain & 0.23 & 0.17 & 8.3 & 0.77 & 0 & 64 & 0.1 & 0.99 \\
\hline Median & $\mathbf{0 . 1 6}$ & $\mathbf{0 . 1 7}$ & $\mathbf{4 . 2 5}$ & $\mathbf{0 . 5 9}$ & $\mathbf{0}$ & $\mathbf{6 1}$ & $\mathbf{0 . 0 6 5}$ & $\mathbf{0 . 9 2}$ \\
\hline
\end{tabular}


Table 2 (continued)

Panel C: German civil law countries

\begin{tabular}{|c|c|c|c|c|c|c|c|c|}
\hline COUNTRY & CAP90 & CAPL & LIQ90 & ACCR & TAXBK & DISCL & SPEND & B590 \\
\hline Austria & 0.1 & 0.1 & 11.7 & - & - & 54 & 0.09 & 0.32 \\
\hline Germany & 0.23 & 0.13 & 22.1 & 0.41 & 0 & 62 & 0.1 & 0.36 \\
\hline Japan & 0.98 & 0.62 & 54 & 0.55 & 0 & 65 & 0.01 & 0.15 \\
\hline South Korea & 0.44 & 0.44 & 30.1 & 0.55 & 0 & 62 & 0.007 & 0.32 \\
\hline Switzerland & 0.7 & 0.62 & 29.6 & 0.32 & 0 & 68 & 0.5 & 0.36 \\
\hline Taiwan & 0.63 & 0.88 & - & - & - & 65 & 0.018 & - \\
\hline Median & $\mathbf{0 . 5 3}$ & $\mathbf{0 . 5 3}$ & $\mathbf{2 9 . 6}$ & $\mathbf{0 . 4 8}$ & $\mathbf{0}$ & $\mathbf{6 3 . 5}$ & $\mathbf{0 . 0 5 4}$ & $\mathbf{0 . 3 3}$ \\
\hline
\end{tabular}

Panel D: Scandinavian civil law countries

\begin{tabular}{|c|c|c|c|c|c|c|c|c|}
\hline COUNTRY & CAP90 & CAPL & LIQ90 & ACCR & TAXBK & DISCL & SPEND & B590 \\
\hline Denmark & 0.29 & 0.21 & 8.3 & 0.55 & 1 & 62 & 0.38 & 0.37 \\
\hline Finland & 0.17 & 0.25 & 2.9 & 0.55 & 0 & 77 & 0.06 & 0.05 \\
\hline Norway & 0.23 & 0.22 & 12.1 & 0.82 & 1 & 74 & 0.14 & 0.78 \\
\hline Sweden & 0.43 & 0.51 & 7.6 & 0.59 & 0 & 83 & 0.3 & 0.21 \\
\hline Median & $\mathbf{0 . 2 6}$ & $\mathbf{0 . 2}$ & $\mathbf{7 . 9 5}$ & $\mathbf{0 . 5 7}$ & $\mathbf{0 . 5}$ & $\mathbf{7 6}$ & $\mathbf{0 . 2 2}$ & $\mathbf{0 . 2 9}$ \\
\hline
\end{tabular}

Panel E: Test of medians (Z statistic)

\begin{tabular}{|l|c|c|c|c|c|c|c|c|}
\hline Comparison & CAP90 & CAPL & LIQ90 & ACCR & TAXBK & DISCL & SPEND & B590 \\
\hline $\begin{array}{l}\text { Common vs. } \\
\text { Civil Law }\end{array}$ & $1.74 *$ & $2.83 * * *$ & $1.89 * *$ & $2.87 * * *$ & $3.22 * * *$ & $2.29 * *$ & 1.18 & $1.56 *$ \\
\hline $\begin{array}{l}\text { Common vs. } \\
\text { French }\end{array}$ & $2.37 * *$ & $3.37 * * *$ & $2.85 * *$ & $2.48 * * *$ & $2.67 * * *$ & $2.94 * * *$ & 1.29 & -0.45 \\
\hline $\begin{array}{l}\text { Common vs. } \\
\text { German }\end{array}$ & -0.06 & -0.48 & 0.9 & $2.51 * * *$ & $3.36 * * *$ & $2.18 * *$ & 0.92 & $2.03 * *$ \\
\hline $\begin{array}{l}\text { Common vs. } \\
\text { Scandinavian }\end{array}$ & 1 & $2.05 * *$ & 0.07 & $1.35 *$ & $2.09 * *$ & -0.92 & 0.07 & $1.89 * *$ \\
\hline
\end{tabular}

All variables are as defined in Table 1.

${ }^{a}$ Civil Law includes French, German, and Scandinavian Law countries. $* * *, * *, *$ Significant at $0.01,0.05$, and 0.10 (one-tailed), respectively. 
Table 3

Regression results on financial development, accounting, and auditing variables

(dependent variables are CAP90, CAPL, LIQ90, ACCR, TAXBK, DISCL, SPEND, and B590) parameter estimates (t-statistics in parentheses)

Panel A: Legal Origin - Common vs. Civil Law

\begin{tabular}{|l|c|c|c|c|c|c|c|c|}
\hline \multirow{2}{*}{ Variable } & \multicolumn{2}{|c|}{ Financial Development } & \multicolumn{3}{c|}{ Accounting } & \multicolumn{2}{c|}{ Auditing } \\
\cline { 2 - 9 } & CAP90 & CAPL & LIQ90 & ACCR & TAXBK & DISCL & SPEND & B590 \\
\hline Intercept & -0.592 & 0.029 & -33.54 & 0.301 & 1.083 & 24.38 & -0.593 & -0.617 \\
& $(-1.25)$ & $(0.06)$ & $(-1.41)$ & $(1.24)$ & $(1.46)$ & $(1.76)^{*}$ & $(-2.02)^{*}$ & $(-1.14)$ \\
\hline LGNP90 & 0.133 & 0.074 & 6.13 & 0.049 & -0.009 & 5.07 & 0.096 & 0.151 \\
& $(2.58)^{* * *}$ & $(1.34)^{*}$ & $(2.37)^{* *}$ & $(1.87)^{* *}$ & $(-0.11)$ & $(3.34)^{* * *}$ & $(2.98)^{* * *}$ & $(2.54)^{* * *}$ \\
\hline CIVIL & -0.414 & -0.492 & -13.98 & -0.212 & -0.727 & -11.45 & -0.198 & -0.441 \\
& $(-3.69)^{* * *}$ & $(-4.24)^{* * *}$ & $(-2.56)^{* * *}$ & $(-3.92)^{* * *}$ & $(-4.34)^{* * *}$ & $(-3.36)^{* * *}$ & $(-2.85)^{* * *}$ & $(-3.49)^{* * *}$ \\
\hline Adj. $\mathrm{R}^{2}$ & 0.33 & 0.36 & 0.20 & 0.36 & 0.46 & 0.35 & 0.23 & 0.30 \\
\hline $\mathrm{n}$ & 29 & 30 & 30 & 26 & 24 & 29 & 30 & 26 \\
\hline
\end{tabular}

Panel B: Legal Origin - Common vs. French - German - Scandinavian

\begin{tabular}{|l|c|c|c|c|c|c|c|c|}
\hline \multirow{2}{*}{ Variable } & \multicolumn{2}{|c|}{ Financial Development } & \multicolumn{3}{c|}{ Accounting } & \multicolumn{3}{c|}{ Auditing } \\
\cline { 2 - 10 } & CAP90 & CAPL & LIQ90 & ACCR & TAXBK & DISCL & SPEND & B590 \\
\hline Intercept & -0.465 & 0.171 & -20.67 & 0.194 & 1.077 & 35.02 & -0.61 & -0.758 \\
& $(-0.92)$ & $(0.31)$ & $(-0.94)$ & $(0.84)$ & $(1.47)$ & $(2.75)^{* * *}$ & $(-1.92)^{*}$ & $(-1.64)$ \\
\hline LGNP90 & 0.118 & 0.058 & 4.715 & 0.06 & -0.008 & 3.88 & 0.097 & 0.166 \\
& $(2.16)^{* *}$ & $(0.97)$ & $(1.97)^{* *}$ & $(2.42)^{* *}$ & $(-0.11)$ & $(2.77)^{* * *}$ & $(2.81)^{* * *}$ & $(3.28)^{* * *}$ \\
\hline FRENCH & -0.454 & -0.534 & -18.04 & -0.171 & -0.711 & $-14 . .26$ & -0.186 & -0.182 \\
& $(-3.69)^{* * *}$ & $(-4.07)^{* * *}$ & $(-3.45)^{* * *}$ & $(-3.27)^{* * *}$ & $(-3.90)^{* * *}$ & $(-4.38)^{* * *}$ & $(-2.36)^{* *}$ & $(-1.37)^{*}$ \\
\hline GERMAN & -0.256 & -0.387 & 2.26 & -0.352 & -0.991 & -11.03 & -0.242 & -0.631 \\
& $(-1.59)^{*}$ & $(-2.24)^{* *}$ & $(0.33)$ & $(-4.88)^{* * *}$ & $(-4.33)^{* * *}$ & $(-2.79)^{* * *}$ & $(-2.52)^{* * *}$ & $(-4.57)^{* * *}$ \\
\hline SCANDINAVIAN & -0.468 & -0.467 & -19.74 & -0.184 & -0.491 & -0.66 & -0.167 & -0.587 \\
& $(-2.69)^{* * *}$ & $(-2.50)^{* *}$ & $(-2.65)^{* * *}$ & $(-2.53)^{* * *}$ & $(-2.13)^{* *}$ & $(-0.15)$ & $(-1.50)^{*}$ & $(-3.95)^{* * *}$ \\
\hline Adj. R ${ }^{2}$ & 0.33 & 0.32 & 0.40 & 0.47 & 0.51 & 0.5 & 0.19 & 0.49 \\
\hline $\mathrm{n}$ & 29 & 30 & 30 & 26 & 24 & 29 & 30 & 26 \\
\hline
\end{tabular}

All variables are as defined in Table 1

$* * *, * *, *$ Significant at $0.01,0.05$, and 0.10 (all one-tailed except intercept), respectively. 
Table 4

Regression results on big five accounting firm market shares in 1990

(dependent variables are SPEND and B590)

parameter estimates (t-statistics in parentheses)

\begin{tabular}{|c|c|c|c|c|c|c|c|c|c|c|c|c|}
\hline \multirow[t]{2}{*}{ Variable } & \multicolumn{6}{|c|}{$\begin{array}{l}\text { SPEND } \\
\end{array}$} & \multicolumn{6}{|c|}{ B590 } \\
\hline & (1) & (2) & (3) & (4) & (5) & (6) & (7) & (8) & (9) & (10) & (11) & (12) \\
\hline Intercept & $\begin{array}{c}-0.581 \\
(-1.53)^{*}\end{array}$ & $\begin{array}{c}-0.679 \\
(-1.83)^{* *}\end{array}$ & $\begin{array}{c}-0.678 \\
(-2.26)^{* *}\end{array}$ & $\begin{array}{l}-0.506 \\
(-1.43)\end{array}$ & $\begin{array}{l}-0.504 \\
(-1.40)\end{array}$ & $\begin{array}{c}-0.543 \\
(-1.84)^{*}\end{array}$ & $\begin{array}{c}-0.73 \\
(-1.15)\end{array}$ & $\begin{array}{l}-0.598 \\
(-0.93)\end{array}$ & $\begin{array}{l}-0.498 \\
(-0.64)\end{array}$ & $\begin{array}{l}-0.532 \\
(-0.89)\end{array}$ & $\begin{array}{l}-0.365 \\
(-0.59)\end{array}$ & $\begin{array}{l}-0.632 \\
(-1.15)\end{array}$ \\
\hline LGNP90 & $\begin{array}{c}0.048 \\
(1.33)^{*}\end{array}$ & $\begin{array}{c}0.081 \\
(2.19)^{* *}\end{array}$ & $\begin{array}{c}0.045 \\
(1.44)^{*}\end{array}$ & $\begin{array}{c}0.080 \\
(2.01)^{* *}\end{array}$ & $\begin{array}{c}0.087 \\
(2.26)^{* *}\end{array}$ & $\begin{array}{c}0.086 \\
(2.65)^{* * *}\end{array}$ & $\begin{array}{l}0.041 \\
(0.71)\end{array}$ & $\begin{array}{c}0.100 \\
(1.58)^{*}\end{array}$ & $\begin{array}{l}0.031 \\
(0.50)\end{array}$ & $\begin{array}{c}0.143 \\
(2.24)^{* *}\end{array}$ & $\begin{array}{c}0.126 \\
(1.89)^{* *}\end{array}$ & $\begin{array}{c}0.151 \\
(2.49)^{* *}\end{array}$ \\
\hline CIVIL & & & & $\begin{array}{c}-0.141 \\
(-1.34)^{*}\end{array}$ & $\begin{array}{c}-0.234 \\
(-2.71)^{* * * *}\end{array}$ & $\begin{array}{l}-0.249 \\
(-1.06)\end{array}$ & & & & $\begin{array}{c}-1.051 \\
(-3.00)^{* * * *}\end{array}$ & $\begin{array}{c}-0.491 \\
(-3.60)^{* * * *}\end{array}$ & $\begin{array}{c}0.25 \\
(0.37)\end{array}$ \\
\hline ACCR & $\begin{array}{c}0.482 \\
(1.98)^{* *}\end{array}$ & & & & & & $\begin{array}{c}1.441 \\
(3.62)^{* * *}\end{array}$ & & & & & \\
\hline TAXBK & & $\begin{array}{c}0.208 \\
(2.73)^{* * *}\end{array}$ & & & & & & $\begin{array}{c}0.423 \\
(3.38)^{* * *}\end{array}$ & & & & \\
\hline$\overline{D I S C L}$ & & & $\begin{array}{c}0.006 \\
(1.93)^{* *}\end{array}$ & & & & & & $\begin{array}{l}0.011 \\
(1.22)\end{array}$ & & & \\
\hline CIVIL*ACCR & & & & $\begin{array}{l}0.142 \\
(0.72)\end{array}$ & & & & & & $\begin{array}{c}1.035 \\
(1.89)^{* *}\end{array}$ & & \\
\hline CIVIL*TAXBK & & & & & $\begin{array}{c}0.159 \\
(1.50)^{*}\end{array}$ & & & & & & $\begin{array}{c}0.262 \\
(1.41)^{*}\end{array}$ & \\
\hline CIVIL*DISCL & & & & & & $\begin{array}{l}0.001 \\
(0.40)\end{array}$ & & & & & & $\begin{array}{c}-0.01 \\
(-0.99)\end{array}$ \\
\hline Adj. $R^{2}$ & 0.20 & 0.25 & 0.20 & 0.20 & 0.23 & 0.22 & 0.34 & 0.31 & 0.00 & 0.37 & 0.32 & 0.27 \\
\hline $\mathrm{n}$ & 26 & 26 & 29 & 24 & 24 & 29 & 23 & 23 & 25 & 23 & 23 & 25 \\
\hline
\end{tabular}

All variables are as defined in Table 1

$* * *, * *, *$ Significant at $0.01,0.05$, and 0.10 (all one-tailed except intercept), respectively. 
Table 5

Regression results on big five accounting firm market shares in 1998 (dependent variable is $\mathrm{B598}$ )

parameter estimates ( $\mathrm{t}$-statistics in parentheses)

\begin{tabular}{|c|c|c|c|c|}
\hline \multicolumn{5}{|c|}{ Panel A: All Countries } \\
\hline Variable & (1) & (2) & (3) & (4) \\
\hline Intercept & $\begin{array}{l}-0.566 \\
(-1.13)\end{array}$ & $\begin{array}{l}-0.449 \\
(-0.86)\end{array}$ & $\begin{array}{c}-0.463 \\
(-0.90)\end{array}$ & $\begin{array}{l}-0.495 \\
(-0.98)\end{array}$ \\
\hline LGNP98 & $\begin{array}{c}0.148 \\
(2.76)^{* * *}\end{array}$ & $\begin{array}{c}0.136 \\
(2.43)^{* *}\end{array}$ & $\begin{array}{c}0.137 \\
(2.48)^{* *}\end{array}$ & $\begin{array}{c}0.141 \\
(2.56)^{* *}\end{array}$ \\
\hline CIVIL & $\begin{array}{c}-0.256 \\
(-2.31)^{* *}\end{array}$ & $\begin{array}{c}-0.349 \\
(-2.26)^{* *}\end{array}$ & $\begin{array}{c}-0.288 \\
(-2.46)^{* *}\end{array}$ & $\begin{array}{c}-0.398 \\
(-2.71)^{* *}\end{array}$ \\
\hline CIVIL*IAS & & $\begin{array}{l}0.133 \\
(0.87)\end{array}$ & & \\
\hline CIVIL*IASPRO & & & $\begin{array}{l}0.005 \\
(0.88)\end{array}$ & \\
\hline CIVIL*CLS & & & & $\begin{array}{c}0.013 \\
(1.61)^{*}\end{array}$ \\
\hline Adj. $R^{2}$ & 0.21 & 0.2 & 0.21 & 0.23 \\
\hline $\mathrm{n}$ & 28 & 28 & 28 & 27 \\
\hline
\end{tabular}

Panel B: Civil law countries

\begin{tabular}{|l|c|c|c|}
\hline \multicolumn{1}{|c|}{ Variable } & $(1)$ & $(2)$ & $(3)$ \\
\cline { 2 - 4 } Intercept & 1.478 & 1.399 & 0.798 \\
& $(1.28)$ & $(1.20)$ & $(0.75)$ \\
\hline LGNP98 & -0.105 & -0.081 & -0.04 \\
& $(-0.87)$ & $(-0.69)$ & $(-0.29)$ \\
\hline IAS & 0.31 & & \\
& $(1.72)^{*}$ & & \\
\hline IASPRO & & 0.009 & \\
& & $(1.55)^{*}$ & \\
\cline { 3 - 4 } & & & 0.015 \\
& & & $(1.73)^{*}$ \\
\hline Adj. $\mathrm{R}^{2}$ & 0.05 & 0.02 & 0.06 \\
\hline $\mathrm{n}$ & 18 & 18 & 18 \\
\hline
\end{tabular}

All variables are as defined in Table 1

***, **, * Significant at $0.01,0.05$, and 0.10 (all one-tailed except intercept), respectively. 
Table 6

Regression results on the development of financial markets in 1990

(Dependent variables are CAP90, CAPL and LIQ90)

parameter estimates (t-statistics in parentheses)

\begin{tabular}{|c|c|c|c|c|c|c|c|c|c|c|c|c|c|c|c|}
\hline \multirow[t]{2}{*}{ Variable } & \multicolumn{5}{|c|}{$\overline{\text { CAP90 }}$} & \multicolumn{5}{|c|}{ CAPL } & \multicolumn{5}{|c|}{ LIQ90 } \\
\hline & (1) & (2) & (3) & (4) & (5) & (6) & (7) & (8) & (9) & $(10)$ & (11) & $(12)$ & $(13)$ & $(14)$ & $(15)$ \\
\hline Intercept & $\begin{array}{l}-0.282 \\
(-0.41)\end{array}$ & $\begin{array}{l}-0.339 \\
(-0.49)\end{array}$ & $\begin{array}{l}-0.128 \\
(-0.20)\end{array}$ & $\begin{array}{l}-0.333 \\
(-0.52)\end{array}$ & \begin{tabular}{|c|}
-0.083 \\
$(-0.14)$
\end{tabular} & $\begin{array}{l}0.171 \\
(0.23)\end{array}$ & $\begin{array}{l}0.145 \\
(0.2)\end{array}$ & $\begin{array}{l}0.516 \\
(0.76)\end{array}$ & $\begin{array}{l}0.361 \\
(0.56)\end{array}$ & $\begin{array}{l}0.574 \\
(0.81)\end{array}$ & $\begin{array}{l}-46.66 \\
(-1.68)\end{array}$ & $\begin{array}{l}-42.21 \\
(-1.48)\end{array}$ & $\begin{array}{l}-32.48 \\
(-1.27)\end{array}$ & $\begin{array}{l}-29.59 \\
(-1.25)\end{array}$ & $\begin{array}{l}-22.76 \\
(-0.74)\end{array}$ \\
\hline LGNP90 & $\begin{array}{c}0.101 \\
(1.36)^{*}\end{array}$ & $\begin{array}{c}0.107 \\
(1.45)^{*}\end{array}$ & $\begin{array}{l}0.087 \\
(1.23)\end{array}$ & $\begin{array}{c}0.101 \\
(1.42)^{*}\end{array}$ & $\begin{array}{l}0.083 \\
(1.17) \\
\end{array}$ & $\begin{array}{l}0.058 \\
(0.74)\end{array}$ & $\begin{array}{l}0.061 \\
(0.77)\end{array}$ & $\begin{array}{l}0.032 \\
(0.44)\end{array}$ & $\begin{array}{l}0.032 \\
(0.46)\end{array}$ & $\begin{array}{l}0.021 \\
(0.27)\end{array}$ & $\begin{array}{c}7.4 \\
(2.50)^{* *}\end{array}$ & $\begin{array}{c}6.92 \\
(2.27)^{* *}\end{array}$ & $\begin{array}{c}6.16 \\
(2.21)^{* *}\end{array}$ & $\begin{array}{c}5.38 \\
(2.08)^{* *}\end{array}$ & $\begin{array}{c}4.94 \\
(1.47)^{*}\end{array}$ \\
\hline CIVIL & $\begin{array}{l}-0.156 \\
(-0.39)\end{array}$ & $\begin{array}{c}-0.344 \\
(-2.20)^{* *}\end{array}$ & $\begin{array}{l}-0.606 \\
(-0.74)\end{array}$ & $\begin{array}{c}-0.371 \\
(-2.22)^{* *}\end{array}$ & $\begin{array}{c}-0.309 \\
(-1.49) *\end{array}$ & $\begin{array}{l}-0.321 \\
(-0.74)\end{array}$ & $\begin{array}{c}-0.441 \\
(-2.69)^{* * *}\end{array}$ & $\begin{array}{c}-1.17 \\
(-1.37)^{*}\end{array}$ & $\begin{array}{c}-0.464 \\
(-2.86) * * *\end{array}$ & $\begin{array}{c}-0.418 \\
(-1.85)^{* *}\end{array}$ & $\begin{array}{l}-1.61 \\
(0.10)\end{array}$ & $\begin{array}{c}-10.52 \\
(-1.58)^{*}\end{array}$ & $\begin{array}{c}-18.49 \\
(0.91)\end{array}$ & $\begin{array}{l}-10.01 \\
(-1.76)^{*}\end{array}$ & $\begin{array}{c}-6.83 \\
(-0.72)\end{array}$ \\
\hline CIVIL*ACCR & $\begin{array}{l}-0.349 \\
(-0.55)\end{array}$ & & & & & $\begin{array}{l}-0.207 \\
(-0.31)\end{array}$ & & & & & $\begin{array}{l}-20.44 \\
(-0.81)\end{array}$ & & & & \\
\hline CIVIL*TAXBK & & $\begin{array}{l}-0.094 \\
(-0.46)\end{array}$ & & & & & $\begin{array}{l}-0.015 \\
(-0.07)\end{array}$ & & & & & $\begin{array}{c}-6.52 \\
(-0.83)\end{array}$ & & & \\
\hline CIVIL*DISCL & & & $\begin{array}{l}0.003 \\
(0.25)\end{array}$ & & & & & $\begin{array}{l}0.009 \\
(0.74)\end{array}$ & & & & & $\begin{array}{c}0.05 \\
(0.16)\end{array}$ & & \\
\hline CIVIL*SPEND & & & & $\begin{array}{l}0.201 \\
(0.45)\end{array}$ & & & & & $\begin{array}{l}0.467 \\
(1.06)\end{array}$ & & & & & $\begin{array}{c}-4.57 \\
(-0.26)\end{array}$ & \\
\hline CIVIL*B590 & & & & & \begin{tabular}{|c|}
-0.196 \\
$(-0.69)$ \\
\end{tabular} & & & & & $\begin{array}{l}-0.144 \\
(-0.46)\end{array}$ & & & & & $\begin{array}{l}-10.29 \\
(-0.78)\end{array}$ \\
\hline Adj. $R^{2}$ & 0.14 & 0.14 & $\overline{0.14}$ & 0.09 & 0.16 & 0.2 & 0.19 & 0.31 & 0.21 & 0.24 & 0.19 & 0.18 & 0.20 & 0.10 & 0.05 \\
\hline $\mathrm{n}$ & 22 & 22 & 24 & 23 & 25 & 23 & 23 & 24 & 24 & 26 & 27 & 26 & 29 & 29 & 25 \\
\hline
\end{tabular}

All variables are as defined in Table 1

$* * *, * *, *$ Significant at $0.01,0.05$, and 0.10 (all one-tailed except intercept), respectively. 
Table 7

Regression results on the development of financial market in 1998 (dependent variables are CAP98 and LIQ98)

parameter estimates ( $\mathrm{t}$-statistics in parentheses)

\begin{tabular}{|c|c|c|c|c|c|c|c|c|}
\hline \multirow[b]{2}{*}{ Variable } & \multicolumn{4}{|c|}{ CAP98 } & \multicolumn{4}{|c|}{ LIQ98 } \\
\hline & (1) & (2) & (3) & (4) & (5) & (6) & (7) & (8) \\
\hline Intercept & $\begin{array}{c}-2.305 \\
(-2.31)^{* *}\end{array}$ & $\begin{array}{c}-2.341 \\
(-2.15)^{* *}\end{array}$ & $\begin{array}{c}-1.797 \\
(-1.81)^{*}\end{array}$ & $\begin{array}{c}-1.831 \\
(-2.18)^{*}\end{array}$ & $\begin{array}{c}-27.3 \\
(-0.30)\end{array}$ & $\begin{array}{l}-17.1 \\
(-0.17)\end{array}$ & $\begin{array}{c}-20.9 \\
(-0.21)\end{array}$ & $\begin{array}{c}-33.2 \\
(-0.36)\end{array}$ \\
\hline LGNP98 & $\begin{array}{c}0.389 \\
(3.63)^{* * *}\end{array}$ & $\begin{array}{c}0.393 \\
(3.36)^{* * *}\end{array}$ & $\begin{array}{c}0.334 \\
(3.13)^{* * *}\end{array}$ & $\begin{array}{c}0.337 \\
(3.57)^{* * *}\end{array}$ & $\begin{array}{c}13.3 \\
(1.34)^{*}\end{array}$ & $\begin{array}{c}12.1 \\
(1.12)\end{array}$ & $\begin{array}{c}12.5 \\
(1.16)\end{array}$ & $\begin{array}{c}13.9 \\
(1.40)^{*}\end{array}$ \\
\hline CIVIL & $\begin{array}{c}-0.788 \\
(-3.53)^{* * *}\end{array}$ & $\begin{array}{c}-0.772 \\
(-2.70)^{* * *}\end{array}$ & $\begin{array}{c}-0.905 \\
(-4.06)^{* * *}\end{array}$ & $\begin{array}{c}-1.011 \\
(-3.10)^{* * *}\end{array}$ & $\begin{array}{c}-59.1 \\
(-2.86)^{* * *}\end{array}$ & $\begin{array}{c}-64.1 \\
(-2.33)^{* *}\end{array}$ & $\begin{array}{c}-57.8 \\
(-2.08)^{* *}\end{array}$ & $\begin{array}{c}-84.1 \\
(-2.39)^{* *}\end{array}$ \\
\hline CIVIL*IAS & & $\begin{array}{l}-0.026 \\
(-0.09)\end{array}$ & & & & $\begin{array}{c}-8.9 \\
(-0.29)\end{array}$ & & \\
\hline CIVIL*IASPRO & & & $\begin{array}{c}0.02 \\
(1.87)^{* *}\end{array}$ & & & & $\begin{array}{c}1.07 \\
(0.05)\end{array}$ & \\
\hline CIVIL*B590 & & & & $\begin{array}{c}0.3 \\
(0.73) \\
\end{array}$ & & & & $\begin{array}{c}38.8 \\
(0.88) \\
\end{array}$ \\
\hline $\operatorname{Adj} . R^{2}$ & 0.37 & 0.35 & 0.43 & 0.43 & $\overline{0.2}$ & 0.16 & 0.12 & 0.19 \\
\hline $\mathrm{N}$ & 30 & 30 & 30 & 28 & 27 & 27 & 25 & 27 \\
\hline
\end{tabular}

All variables are as defined in Table 1.

$* * *, * *, *$ Significant at $0.01,0.05$, and 0.10 (all one-tailed except intercept), respectively. 
Figure 1

Investor Protection Framework

\begin{tabular}{|ccc|}
\hline $\begin{array}{l}\text { Investor } \\
\text { Protection } \\
\text { Laws }\end{array} \longrightarrow \begin{array}{c}\text { Financial } \\
\text { Markets } \\
\text { Development }\end{array} \longrightarrow \begin{array}{c}\text { Role of Accounting } \\
\text { and Auditing In } \\
\text { Corporate Governance }\end{array}$
\end{tabular}$\longrightarrow \quad$\begin{tabular}{c}
$\begin{array}{c}\text { Observed } \\
\text { Properties } \\
\text { of Country } \\
\text { Specific Financial } \\
\text { Statements }\end{array}$ \\
\hline
\end{tabular}

